\title{
Women's Role In Combating Population Explosion; Public Sector Efforts In Pakistan
}

\author{
Jugnoo Salahuddin \\ Department of Social Work \\ University of Karachi
}

\begin{abstract}
This article is an extract from a much larger study with broader objectives. In this specific article the detailed background of the Government efforts for nipping the bud of population explosion is explored. The actual study was based on the "performance evaluation" of 607 lady health workers from 5 districts of Karachi division, using quantitative method of data collection. This article informs the readers the strategies adopted by the Government of Pakistan in combating population growth between the years 1955-1998. It reveals factors responsible for the failure of family planning programme in Pakistan and also those, which have played a positive role in its propagation.
\end{abstract}

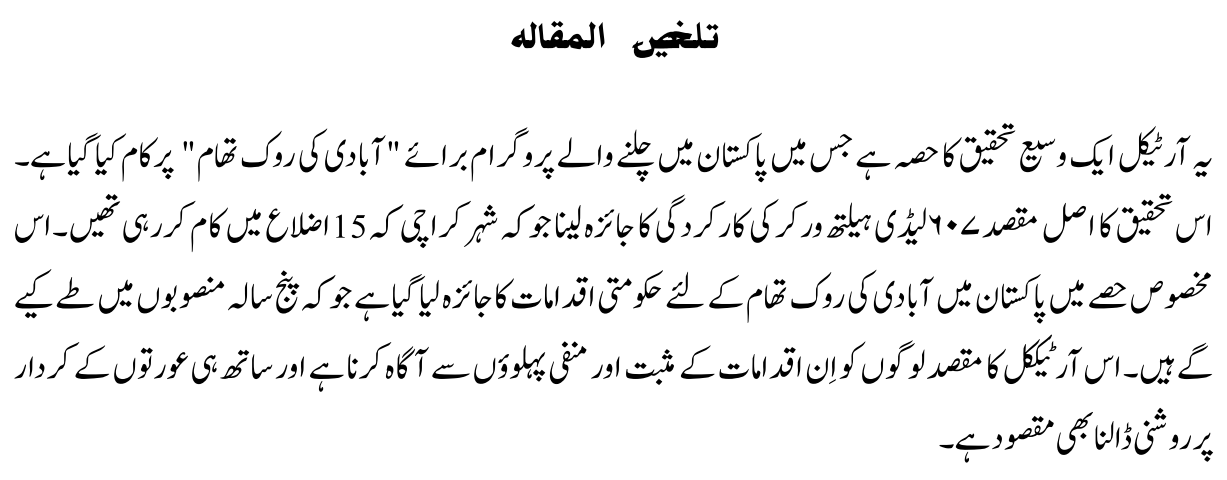

\section{Objectives}

- To find out the role of women in dealing with an enormous social problem of "overpopulation" since 1955 by Government of Pakistan

- To understand the weakness and strengths of Family Planning programmes designed by Pakistan's Government.

\section{Introduction}

Few goals are universally shared and among them is the will for good health and life. In 1945, United Sates secretary of state, Cordel Hull stated, "The battle for peace has to be fought on two fronts. The first is the security front where victory spells freedom from fear. The second is the economic and social front, where victory spells freedom from want". 
Today no problem is more urgently important to the well being of mankind than the limitation of uncontrolled population growth. It is a problem, the effects of which are worldwide, demanding the attention of all nations ${ }^{1}$.

"Predicting future social and population conditions a British social scientist Rousas.J.Rushdory, calculated, that with the present population of the world now about 6 billion and doubling every 37 years, we would reach the ultimate terrestrial of 60 billion humans in somewhat less than 1000 year. At that stage people; will be jammed together so tightly that earth itself will glow orange red from the heat". 2

Too rapid population growth hinders a nation's ability to progress and to satisfy the growing demands of its people for a better life which is the ultimate goal of any welfare state. The alarming situation came for the world during 1920 to 1950 . The rate of growth was nine per thousand almost $1 \%$ per annum. During the last decades the growth of population was even double as compared to the growth which occurred during 30 years from 1920 to 1950 for the world as whole.

The share of ASIA and AFRICA in the total growth remained high and most of the growth will take place in the less developed nations that are not equipped to absorb it and deal with it. This is what is meant by "POPULATION EXPLOSION". Population explosion raises many socially ill conditions that play vital role in the declining of societies. World Development Report 1990, on poverty provided and overviewed development indicators of the world which included education, health, economic growth, political systems, family planning programmes and other to reduce the level of poverty and suffering. According to this report 1 billion people lived in poverty in the developing world. Nearly half of the poor lived in the South Asia region that accounts for roughly $30 \%$ of the world's population. ${ }^{3}$

The drive for fertility regulation has been evident in all cultures at all times, even in societies in which social or religious rules favoured the abundant production of children. In general people have not sought to escape parenthood, but simply to limit reproduction to bring it within the dominion of human will and intelligence. In Modern times, "Family planning means, Family welfare" It is Planned Parenthood. It is the creation of happy homes. It means planning the family in such a way that the couple; may get children by choice and not by chance. Family Planning means to limit either size of the family and reducing the dependence load. ${ }^{4}$

Family planning is not merely birth control, but is synonymous with the health, living conditions and the happiness of the family. Family planning teaches us how to live, not merely to exist. It is child spacing which is not necessarily natural and can be influenced 
thorough family planning method. More precisely, it means birth control or contraception to regulate by choice the number of pregnancies and children within the family.

In order to assess the role of the public sector efforts in combating population explosion, we will have to go through the key highlights of the 8 five year plans of the Government which are shared below.

\section{First Five Year Plan 1955-60}

By 1955, voluntary organisations built up pressure sufficiently for the Government to recognise population growth as a serious social and economic issue. In the First Five year Plan (1955-60), a token provision of half a million rupees was made for support of family planning activities through voluntary agencies. This money was utilized in creating a network of such efforts and in persuading the Government to take some responsibility for direct operations in this filed ${ }^{5}$.

\section{Second Five Year Plan 1960-65}

Sustained efforts by pressure groups led to the formulation of this first national Family Planning Programme with an active role for the public sector. The Second Five Year Plan (1960-65) allocated over thirty million rupees, primarily for the supply of contraceptive through the hospitals and dispensaries of the Provincial Health Departments. Provision of family Planning services to 600,000 couples was envisaged ${ }^{6}$. In many cases this resulted in a few condoms in the furthest dispensaries kept under lock and key along with broken equipment for inventory purposes. Thus, the logistics of using the Health Outlets were only partially effective, at least with one time supplies, as dispenser and doctors were often not willing to distribute such polluting items even to needy clients. A cell started operating in the planning commission to prepare an elaborate plan with an independent, single- purpose organisation spread over the entire country, down from the centre to the province, to the provisional council level, rooted at the grass root unit of Basic Democracy, each unit covering a population of 10,000 living in 3,4 and 5 villages.

\section{Third Five Year Plan 1965-70}

The family planning programme gained momentum in the third five year plan. The third Five Year Plan raised a structure of Family Planning which, stood like a minaret at the end of journey through a desert. The Family Planning movement was properly launched in the third five year plan by President Muhammad Ayub Khan. The scheme had six basic elements which were adopted from experienced gained during 2 nd five year plan which were made in the fields of training and research. Research in family planning includes a wide range of activities from the clinical testing of a contraceptive to its actual 
acceptance, effectiveness, side effects, reaction of the family and the community. As such most of the research activities in family planning are Multi-dimensional and cut across many fields of specialization and thus calls for an interdisciplinary approach.

"The aim of research efforts should not be merely to find out ways and means to prevent pregnancies, but should also be to help develop the total programme in which specialists and workers in the fields of medicine, social sciences and administration co-operates with each other and work as a team for furtherance of the objectives of the programme. It is proposed in the scheme to cover all the 20 million fertile couples in Pakistan with family planning programme by the year $1970^{7}$.

The programme had three salient features:

1. Initially Family Planning as a government activity was separated from the Health Division and placed in a newly constituted Family Planning Division.

2. Emphasis was put on the distribution of IUDs rather than on conventional contraceptives.

3. In addition, a cadre of 'Dais' (midwives) was recruited to motivate women to use IUDs but the programme failed to produce any of the promised results. According to the National Impact Survey carried out in 1968-1969, over 80 percent of women contacted by the surveyors were in favour of family planning but only 4 percent were found to be practising any methods of birth control; 70 percent knew of at least four methods to delay pregnancy; 64 percent did not know anyone in the local area who was giving advice and service on family planning; and 6 percent reported they had contact with such persons or centres.

In other words, the programme might have succeeded in motivating women to favour family planning but it could not get them to practice it. There were two main reasons for the gap between interest and practice: the attitude of the family involved (husbands in particular) and the lack of availability of family planning services.

It is these years when a large number of publications came out on Islam and Family Planning, MCR and Family Planning, Nutrition/Education/Family Budget and Family Size, apart from those on choice of contraceptives, location of supply and service points, removal of popular misconceptions and traditional taboos. Interpersonal communication with women was mobilised in a majority of villages through fifteen to twenty thousand Dais, based in about ten thousand villages whose contacts with families were multipurpose and long-established. Family Planning stalls at local fairs, radio and newspaper messages provided umbrella coverage to the nationwide movements.

Simultaneously, increasing market access to contraceptives like tablets, liquid foam and condoms was provided by registering shopkeepers and other agents in thousands who 
were meant to multiply sales on a commission basis. The commission however, was not very significant; pressures of demand were not very striking and the logistics of re-supply were not re-assuring. The target break-down of expected distribution during 1965-70 was worked out theoretically as follows:

- through village Dais: $50 \%$

- through the village shopkeepers, retailers and grocers (selected by the Union Councils): $10 \%$

- through doctors, trained midwives, lady health visitors, medical houses pharmacists, and stores outside urban locations: $10 \%$

- through pharmacists, factories, workshops, stores, and other dealers in allied goods in urban areas: $15 \%$

- Rest through doctors, trained midwives, lady health visitors and allied personnel in urban areas.

\section{No Plan Period 1971-76}

After mid 1968, the operational national programme was subjected to scathing criticism and field evaluation was conducted by civil and military teams. However, an experimental district project was accepted as having demonstrated the desirability of substituting village Dais with married couples and educated workers capable of maintaining an ever expanding range of records.

The Government accepted the recommendation along with the recommendation to completely federalise the Programme. The entire Dais in the programme was discontinued, leaving the super-structure designed to support them hanging in the air. Only later, did the new system of grass root contact start coming into operation. The decision to federalise, however, was never implemented.

The continuous Motivation System ${ }^{8}$ aimed at overcoming some of the imperfections experienced during the Third Five Year Plan operations e.g.

1. It provided for contacts with all fertile couples in the project areas as listed after a house to house survey;

2. Mobility of workers and proper reporting of performance were arranged through a stream-lined system of training, supervision and inspection. One Family Planning Officer supervised six men-women teams of field workers/motivators and one Inspection-cum-training officer offered audit and support to 36 teams;

3. Emphasis was laid on continuity and regularity of use, not merely on initial acceptance;

4. Service was planned to be domiciliary, thus avoiding the previous dependence upon clinics; 
5. No single method of contraception was promoted to the near-exclusion of others. (Later on, under donor pressure, Oral Pills inundation was vigorously attempted);

6. A complete record of couples contacted, showing their response to contacts, methods in use, subsequent advice, assistance given to them and births averted, if any, was arranged for each village and Mohallah

The Government re-named the Family Planning Programme as Population Planning Programme in 1974 which encouraged the programme planners to look forward to getting closer to the development plans of other organisations like Agriculture, Rural Development, Education, Housing, Labour Welfare, Employment and Manpower, Urban and Rural planning in order to project population planning elements into them. The programme planners also looked forward to projecting their ideas into legislation and regulations in order to secure a desired additional impact of a supportive framework of administrative and financial laws and rules upon growth, migration pattern and welfare of Rural and urban populations. The planners aimed no longer to confine themselves to fertility control through supply of clinical and conventional methods of contraception but to use the whole state apparatus. (Fourth Five Year Plan 1970-75)

By 1975, after two more years of implementation, CMS operations were visible to more than two thirds of the country's population with the following structure in more densely populated areas:

1. At the grass root level, Dais had been replaced by male-female teams, each covering about 10-15 thousand population

2. Above them was the Population Planning Officer (PPO) for every six teams of workers, responsible for direct supervision and contraceptive logistics

3. Slightly above the PPO was the Inspection-cum- Training Officer covering six PPOs with 36 teams of workers

4. District Population Planning Officers became independent of the hold of the Deputy Commissioners who, as Chairmen of the District Family Planning boards, had exercised a growing hold upon the facilities, particular transport facilities, offered by the Programme

5. The clinics increasingly offered MCR Services, including medicines for certain ailments for mothers and children.

6. Lady Motivators were provided in most of the established hospitals to offer Family Planning advice and services - for women in-door and out-door patients.

It was this period when the family planning services for the first time was integrated with the health component and community involvement was recognised as an agent of change. CMS can be identified as the first attempt to introduce community participation approach to tackle with a social problem and attain sustainable development. 
A Demographic Policy and Action Research Centre were also initiated to help extend the programme beyond the limited field of fertility control. It started working with specific actions on Laws and Regulations, Rural Development and Agriculture, Portable Water and Environmental Sanitations, Population Education, Labour Welfare and Employment. Its incentive was to identify ways and means of introducing population control motivation into development programmes, taxation and regulatory activities of the Government. A couple of drafts to amend existing laws were submitted to the highest levels in the Government and one for amendment of the law on abortion in the Penal Code.

Special short-term training courses were arranged for the front line workers of Agriculture, Social welfare, People's Works Programme and other nation building Departments.

Negotiations were started with the established NGOs to explore the possibility of a vision of operational activities in terms of defined territorial or functional jurisdictions. Formal contacts were made with major distributors of consumer goods in order to ensure a regular supply of conventional contraceptives through a network of shops and large scale deploying establishments. But absence of rural coverage, demands for high commissions in distributors, partially justified fears in commercial agencies of discrediting their other activities by being associated with contraceptive supply, hindered any concrete progress in its area.

\section{Program Destabilisation 1977 - 1981}

Population activities were almost dormant in the late 1970s, however because of the after-effects of the 1977 general elections and the programme was made centralised most probably because of transition to a military government. Between 1977 and 80 there were essentially no field activities or motivation campaigns in the country. Change of political regime took place whose orthodox religious orientation could not support Population Programme on such a massive public scale. The use of mass media was banned for the programme. The person to person motivation through married couple's teams of motivators was forbidden. Mobility expenditure was virtually ended. Commissions and Committee were formed to weed out "Undesirable elements" of the programme ${ }^{9}$.

\section{Fifth Five Year Plan 1978 - 1983}

In 1980, some signs of possible legitimisation appeared with the appointment of an Advisor on Population Welfare. A fresh plan was drafted for $1980-83$. About $50 \%$ of the operational functionaries (about 7500 out of a total of 15000 approximately) were laid off 
in the process of absorption of the employees of formally autonomous bodies into the regular Government Service. The total staff was reduced to this level by splitting the plan requirement into individual projects (with relatively limited activities and smaller population coverage)

Not used to a project approach, the Population programme planners and managers did not easily adjust to the compartmentalisation of the programme into annual plans for 36 projects with their varying schedules for budgetary sanction, submission of accounts on different formats and other demands to satisfy Federal Government, Provisional Government and different other donors.

In 1986, there reappeared an opening for an active communication strategy to use the mass media and interpersonal communication. But it has not proved easy to deal with mass media managements after this long period of ban, in an atmosphere of censorship nor was it very clear. It was a challenge that, how interpersonal communication could be re-vitalised knowing that past experiments had been short termed. During the year $1986-$ 1988, experimental innovations in the communication and supply scheme were made with Dais, Hakeems, Barbers NGO's, Social Marketing of condoms, but the programme still seems to be in search of clear messages and the appropriate media. The Long term distancing of the Programme from the people as a result of bureaucratisation and politicisation has produced a major challenge for the 1990's.

Re-provincialisation of field operations has also produced its own organizational problems. A Presidential Order to this effect was issued in 1983. Since then a whole Five Year Plan period has passed and the combination of Federal- Provincial and budget issues had yet to be fully sorted out. For example, duplications of functions, damaging delays in disbursing funds, and continuing chagrin among the staff of Provinces over promotions, transfers and other personal claims of frequently moved personnel continue to plague the Programme. But in the meantime, the Programme has grown in staff numbers and many of the former staff has been re-absorbed.

\section{Sixth Five Year Plan 1983- 1988}

During the Sixth Plan period the total allocation for Population Welfare activity was Rs.2.3 billion of which the Annual Development Programme (ADP) for the projected programme allocation was Rs.2.2 billion (Sixth Five Year Plan 1983-1988). By the end of the Sixth Plan, it was estimated that the programme had utilised Rs.1.7 billion or 77.2 per cent of the allocation ${ }^{10}$. 


\section{Seventh Five Year Plan 1988- 93}

The seventh plan despite missing so many demographic objectives in the past remains optimistic and suggestive that the programme has still not lost its appetite for targets in the future. The programme aimed to raise practices of family planning from 12.23 by the year 1992-93 and preventing 3.17 million births ${ }^{11 .}$

It was the seventh five year plan that population welfare department expanded their services of contraception to rural communities and introduce on pilot basis a rural based approached called "Village Based Family Workers Team". These workers provided family planning and mother and child health care services at the door steps of rural population. The scheme was expanded during the Eight Five year plan to cover all fifteen districts of the province of Sindh by enrolling 1950 VBFPW. A situation analysis by population council showed that the scheme is widely accepted and recognized and shall be continued in eight five year plan.

\section{Eighth Five Year Plan 1993-98}

In the eighth plan it was decided to increase the village based family planning workers (VBFPWs) from 6.547 to 12.047 . In the same plan Health Ministry has also introduce a special programme for mother and child health and family planning. Following the footsteps of CMS, the then Prime Minister "Mohtarama Benezir Bhutto launched a special programme called, "Prime Minister's Programme for Family Planning and Primary Health Care". The programme constitutes the main thrust of the extension of outreach services particularly in the rural areas and less developed urban areas. It aimed to deploy 100000 (1 Lakh) women workers to provide health services at their doorsteps at grass root level (Eighth Five Year Plan 1993-98). These women workers are now named as LHWs (Lady Health Workers) initial 33,000 Village Health Workers will be deployed

from the rural areas. The VHWs will receive a formal comprehensive training to deliver family planning and Primary Health Care. ${ }^{12}$

\section{Factors played positive role in the propagation of the Family Planning Programme in Pakistan}

- Early identification of population explosion issues at government level and allocation of budget for research activities.

- Involvement of local communities as a strategic solution.

- Involving women in the process.

- Involving other sectors as rural development, Labour welfare, and communication system in order to diffuse the bomb.

- Introduction of the continuous monitoring system. 
- Capacity building of local women workers.

- Conceptual shift from family planning to population welfare.

- Service provision at the doorstep of poor rural communities.

\section{Weak Links of the Family Planning Programme in Pakistan}

- Weak research activities for developing a comprehensive plan of action.

- Too large implementing infrastructure and change in the government's.

- Ignoring the gate keeper's involvement in family planning programmes, at the initial stages.

- Delayed comprehensive communication policy for effective dissemination of the programme.

\section{Conclusions}

After analysing the Government's efforts through various five year plans, it is evident that the major development in this sector has happened during democratic governments. It is a positive sign that Government efforts have increased both in terms of funds and manpower particularly after the second five year plan since its inception in 1960.

It is a positive sign that, women are recognised as change agents, throughout history in the process of community development even, in a third world country like Pakistan. It is a fact that women can play a significant role in developmental process and nation building programs if they are given their legitimate rights on equity basis. Developing and enhancing their decision making process with respect to their family and health would be the key towards progress. The efforts of public sector in controlling population explosion should not work in isolation and should closely involve other stakeholders working in this area that includes local and international NGO's, CBOs and the private sector for a prosperous Pakistan.

\section{End Notes}

1. Rockefeller, John D (Ed) Family Planning Programmes, An international survey; toward the enrichment of life, New York: Basic Books Publishers. 1969.

2. Rousas.J. Rushdory. (1970).The Myth of Over Population, London: Macmillan publications.

3. World Development Report on Poverty.(1990), Published for World Bank, New York: Oxford University Press. 
4. Rabbani Rabbani.F.(Ed).(2004). Manual for community health care providers, Dept of Community Health Sciences, AKU.

5. Pakistan First Five Year Plan 1995 - 1960, Planning Commission of Pakistan, Govt of Pakistan http://www.pc.gov.pk/fiveyear1st.htm (accessed 15 December 2012)

6. Pakistan Second Five Year Plan 1960-65, Planning Commission of Pakistan, Govt of Pakistan http://www.pc.gov.pk/fiveyear2nd.htm (accessed 15 December 2012)

7. Pakistan Third Five Year Plan 1965 - 1970, Planning Commission of Pakistan, Govt of Pakistan http://www.pc.gov.pk/fiveyear3rd.htm, (accessed 15 December 2012)

8. Pakistan Fourth Five Year Plan 1971 - 1976, Planning Commission of Pakistan, Govt of Pakistanhttp://www.pc.gov.pk/fiveyear4th.htm, (accessed 15 December 2012)

9. Pakistan Fifth Five Year Plan 1978-83, Planning Commission of Pakistan, Govt of Pakistanhttp://www.pc.gov.pk/fiveyear2nd.htm , (accessed 15 December 2012)

10. Pakistan Sixth Five Year Plan 1983 - 1988, Planning Commission of Pakistan, Govt of Pakistanhttp://www.pc.gov.pk/fiveyear6th.htm (accessed 15 December 2012)

11. Pakistan Seventh Five Year Plan 1988 - 1993, Planning Commission of Pakistan, Govt of Pakistanhttp://www.pc.gov.pk/fiveyear7th.htm, (accessed 15 December 2012)

12. Pakistan Eighth Five Year Plan 1993 - 1998, Planning Commission of Pakistan, Govt of Pakistanhttp://www.pc.gov.pk/fiveyear8th.htm, (accessed 15 December 2012)

Jugnoo Salahuddin is Assistant Professor in the Department of Social Work, University of Karachi. 